\title{
An overview of composition, properties, and applications of Biodentine
}

\author{
Navya Sri Kadali1,, , Rama Krishna Alla ${ }^{2}$, Ramaraju AV ${ }^{3}$, Suresh Sajjan MC ${ }^{3}$, Satyanarayana Raju \\ Mantena $^{3}$, Rudraraju Venkateswara Raju ${ }^{4}$ \\ ${ }^{1}$ Lecturer, ${ }^{2}$ Associate Professor, Department of Dental Materials, Vishnu Dental College, Bhimavaram, \\ Andhra Pradesh, India. \\ ${ }^{3}$ Professor, ${ }^{4}$ Lecturer, Department of Prosthodontics, Vishnu Dental College, Bhimavaram, Andhra Pradesh, \\ India.
}

\section{N F O R M A T I O N A B S T R A C T}

\section{Article History}

Received $7^{\text {th }}$ June 2021

Accepted $7^{\text {th }}$ October 2021

Available online

$1{ }^{\text {st }}$ December 2021

\section{K E Y W O R D S}

Biodentine

MTA

Dycal

Tricalcium Silicate cement

Calcite
A series of events leads to loss of tooth structure by dental caries, tooth wear and trauma, which is often replaced by inert dental materials that replace the bulk of the tooth. If pulp health is affected, a series of interventions need to be undertaken. Initially, the pulp vitality needs to be maintained. Later, elimination of infection and filling of the pulp space is necessary. When pulpal involvement occurs the choice of material has to change, and materials that interact with the pulp are indicated. Interactive materials used for dental procedures include calcium hydroxide in its various presentations and hydraulic calcium silicate cement. Biodentine is a promising dentine substitute that has been recently introduced in dentistry. Although many other materials like Glass Ionomer Cement (GIC), composite and Mineral Trioxide Aggregate (MTA) are available for repair of dentin loss in tooth structure, none of them possesses ideal properties. Despite many advantages, MTA has been replaced by Biodentine, which is a new calcium silicate -based material, due to its limitations. It has good handling properties, short setting time, and improved mechanical properties. Biodentine was designed explicitly as a "dentine replacement," with applications ranging from endodontic repair to pulp capping.

\section{Introduction}

Glass-Ionomer cement has been used extensively in deep carious lesions and dentine loss in the coronal part. However, its inherent limitation of not stimulating any reparative dentin formation led to the evolution of many other materials [1-3]. When pulpal involvement occurs, the material choice must change, and materials that interact with the pulp or the dentine are indicated. Calcium hydroxide, in various forms, and, more recently, hydraulic calcium silicate cement, are interactive materials used in dental procedures. They can even be used on moistened tooth surfaces. In endodontic therapy, the practitioner employs endodontic repair materials that are insoluble in oral fluids, maintain an adequate seal, are dimensionally stable, non-resorbable, radioopaque, and biocompatible. Amalgam, zinc-oxide eugenol cement, composite resin, and glassionomer cement have all been utilised in the past for retrograde filling and perforation repair. Unfortunately, none of these materials has been able to meet all of the ideal material's requirements. 
In the early 1990s, mineral trioxide aggregate (MTA), a biomaterial, was investigated for its potential in restorative dentistry. Its multiple applications include direct \& indirect pulp clapping, the formation of the apical plug, root-end filling, perforation repair, furcation repair, repair of resorptive defects, and the management of immature apices (Apexogenesis/ Apexification) etc. [4-9]. However, this material has a few inherent limitations, including difficulty in manipulation, a prolonged setting time, and is expensive [10].

Septodont's research group recently developed Biodentine ${ }^{\mathrm{TM}}$, a novel dental material class that combines high mechanical qualities with exceptional biocompatibility and bioactive behavior. Biodentine is the first -in-one biocompatible dentine substitute, based on Active Biosilicate Technology ${ }^{\mathrm{TM}}$, that is used to restore and endodontically treat damaged dentine [2]. In 2009 , it was made commercially available.

\section{Composition of Biodentine}

Biodentine is available in powder and liquid forms. The powder primarily consists of Tricalcium silicate $\left(3 \mathrm{CaO} \cdot \mathrm{SiO}_{2}\right)$ and Di-calcium silicate $\left(2 \mathrm{CaO} \cdot \mathrm{SiO}_{2}\right)$. They regulate the setting reaction and act as core materials. Calcium carbonate $\left(\mathrm{CaCO}_{3}\right)$ acts as a filler and is responsible for improving mechanical properties. A radiopacifier may also be present such as Zirconium dioxide $\left(\mathrm{ZrO}_{2}\right)$.

The liquid contains Calcium chloride $\left(\mathrm{CaCl}_{2} \cdot 2 \mathrm{H}_{2} \mathrm{O}\right)$, which acts as an accelerator and regulates the setting reaction. Water reducing agent (Super-plasticizer) such as a hydro-soluble polymer is added to reduce the amount of water required for the mix (water/ cement), decreases viscosity and improve cement handling characteristics [11].

\section{Setting reaction}

Initially, the reaction starts with the hydration of the tricalcium silicate, leading to hydrated calcium silicate gel (CSH gel) and calcium-hydroxide [12]. The cement located in inter-grain areas contains a high level of calcite (CaCO3) content. The tricalcium silicate is hydrated by the dissolution and precipitation of calcium silicate hydrate. In general, it is represented by chemists as $\mathrm{C}-\mathrm{S}-\mathrm{H}$; where ' $\mathrm{C}$ ' is $\mathrm{CaO}$, ' $\mathrm{S}$ ' is $\mathrm{SiO} 2$, and ' $\mathrm{H}$ ' is H2O. The calcium hydroxide takes origin from the liquid phase. C-S-H gel layer formation occurs after the nucleation and growth on the tricalcium silicate surface. The remaining unreacted tricalcium silicate grains are surrounded by layers of calcium silicate hydrated gel, which are relatively impervious to water, thereby slowing the further reactions. The $\mathrm{C}-\mathrm{S}-\mathrm{H}$ gel formation is due to tricalcium silicate's permanent hydration, which gradually fills in the spaces between the tricalcium silicate grains. The following chemical equation summarises the complete hydration reaction [12].

$$
2\left(3 \mathrm{CaO}^{-\mathrm{SiO}_{2}}\right)+\underset{\mathrm{C}-\mathrm{S}-\mathrm{H} \text { gel }}{6 \mathrm{H}_{2} \mathrm{O}} \rightarrow \underset{\mathrm{CaO}}{2 \mathrm{SiO}_{2}} \cdot 3 \mathrm{H}_{2} \mathrm{O}+3 \mathrm{Ca}(\mathrm{OH})_{2}
$$

\subsection{Structure of cement}

The set cement consists of calcite rich $\left(\mathrm{CaCO}_{3}\right)$ structures of variable sizes. The crystals of $\mathrm{CaCO}_{3}$ are diamond-shaped (or rhombohedra form) and observed at the surface. Taylor (1997) observed that calcium- hydroxide crystallizes in the form of a hexagonal plate [13]. The surface of the $\mathrm{CaCO}_{3}$ crystals is rough and irregular. Therefore, $\mathrm{CSH}$ gel is considered the cement matrix, and the crystals of $\mathrm{CaCO} 3$ fill the spaces between grains of cement. Calcite $\left(\mathrm{CaCO}_{3}\right)$ has two distinct functions including Calcite acts as an active agent, is implicated in the process of hydration, and as a filler that improves the mechanical properties of the cement [14]. The hardening process results from the formation of crystals that are deposited in a supersaturated solution. Setting reaction of $3 \mathrm{CaO}_{\mathrm{SiO}}{ }_{2}$ includes four elements such as the unreacted particles, surface products ( $\mathrm{CSH}$ gel), the content of the pores $\left(\mathrm{Ca}(\mathrm{OH})_{2}\right)$ and porous capillary space [15].

\section{Properties of Biodentine}

\subsection{Setting time}

Compared to MTA, Biodentine has a shorter setting time and is in the range of $9-12$ minutes. The main reason for the shorter setting time is the presence of Calcium chloride, which acts as an accelerator. Further, this material also contains a Hydro-soluble polymer, which acts as a water-reducing agent [16]. The initial and final setting times of Biodentine and MTA are given in table 1.

Table 1: Setting time of MTA and Biodentine

\begin{tabular}{lcc}
\hline Materials & $\begin{array}{c}\text { Initial setting time } \\
\text { (Minutes) }\end{array}$ & $\begin{array}{c}\text { Final setting time } \\
\text { (Minutes) }\end{array}$ \\
\hline Biodentine & 6 & 10.1 \\
\hline MTA & 70 & 175 \\
\hline 1
\end{tabular}




\section{2 Adhesion}

The Biodentine adheres to the dental surfaces with the help of physical bonding by ion exchange. The Physical process of crystal growth within dentine tubules leads to a micromechanical tag that gives a long-lasting seal. Compared to the MTA and Dycal, Biodentine exhibits a greater bond strength with the dental surfaces [14].

\subsection{Density and porosity}

The use of hydro-soluble polymer in Biodentine composition reduce the amount of water that exhibits a positive influence on the density and porosity of Biodentine. The lower porosity of Biodentine leads to higher mechanical strength. Also, it exhibits a lower porosity compared to Dycal and MTA [16].

\subsection{Radiopacity}

Biodentine is a radiopaque material as it contains zirconium oxide, which allows easy identification on the radiographs. According to the ISO standard 6876 , Biodentine shows a radiopacity equivalent to $3.5 \mathrm{~mm}$ of aluminium. This value obtained is over the minimum requirement of ISO standard ( $3 \mathrm{~mm}$ aluminium) and makes BiodentineTM particularly suitable in the endodontic indications of canal repair $[16,17]$.

\subsection{Compressive strength}

The cement must have the capacity to withstand masticatory forces; in other words, sufficient compressive strength to resist external forces [18]. Biodentine has the unique property of demonstrating its ability to improve compressive strength over time until it reaches a level comparable to natural dentine [19]. In a study, Grech et al. (2013) [20] reported that the highest compressive strength with the Biodentine compared to Bioaggregate, Tricalcium-Silicate cement and Intermediate Restorative Materials (IRM). This increase in compressive strength can be attributed to the requirement of lower water: powder ratio of the Biodentine as it contains a water-soluble polymer in the liquid. Kayahan et al. (2013) [18] evaluated the compressive strength from another perspective and attained conclusions specifically on clinical usage. Acid etching was done for mechanical adhesion of Biodentine to the tooth structure. Numerous studies aimed to assess whether there will be any alteration in the compressive strength due to the etching process. They concluded that the acid etching process after seven days did not reduce the compressive strength of ProRoot MTA and Biodentine [18]. In a study by Koubi et al. [19], Biodentine was used as a posterior restoration and revealed favourable surface properties such as good marginal adaptation until six months. The compressive strength of Biodentine will be $100 \mathrm{MPa}$ in the first hour, which will be increased to a value of 300 MPa after one month. This value becomes relatively stable and is in the compressive strength of natural dentine (297MPa).

\subsection{Flexural strength}

High flexural strength is a compulsory prerequisite for any restorative material for its long-term efficiency in the oral cavity. The three-point bending test was used to measure the flexural strength and is of high clinical significance. The bending value obtained after 2 hours was $34 \mathrm{MPa}$ compared with other materials such as 5$25 \mathrm{MPa}$ for the Conventional Glass Ionomer Cement; 17-54 MPa for Resin modified GIC; and 61-182 MPa for Composite resin [21]. Therefore, it has been inferred from the test that the bending resistance of Biodenti$n \mathrm{e}^{\mathrm{TM}}$ is superior to conventional GIC but much lower than the composite resin.

\subsection{Microhardness}

There is an increase in microhardness of Biodentine with time. After one month, the hardness of Biodentine reaches the same range as natural dentine [14].

\subsection{Biodentine interfaces}

Biodentine's interface with adjacent phosphate-rich hard tissue substances is improved by the deposition of calcium phosphate crystals on the surface. As a result, Biodentine is more resistant to acid erosion and microleakage. Biodendine appeared to have more resistance to decay and microleakage than MTA, Dycal and GIC [22].

\subsection{Discoloration}

Biodentine exhibits colour stability over five days and can serve as an alternative for use under light cure restorative materials in highly esthetic areas [23].

\subsection{Antibacterial activity}

Biodentine exhibits a significant amount of antibacterial activity as well. Calcium hydroxide ions released 
from cement during the setting phase of Biodentine increases $\mathrm{pH}$ to 12.5 , which inhibits the growth of microorganisms and can disinfect the dentin.

\subsection{Biocompatibility}

According to Laurent et al. [24], Biodentine is nontoxic and has no adverse effects on cell differentiation and specific cell function. They reported that Biodentine increases TGF-B1 (growth factor) secretion from pulp cells which causes angiogenesis, recruitment of progenitor cells, cell differentiation and mineralization. The material is inorganic and non-metallic and can be used in direct and indirect pulp capping procedures as a single application dentin substitute without any cavity conditioning treatment [2].

\subsection{Stability in the oral environment}

Biodentine is not that stable as a composite material so that it is not suitable as permanent enamel replacement material. When compared to other Portland cement-based materials, Biodentine is stable enough to use as a temporary filling in the load-bearing areas [22].

\subsection{Washout resistance}

Washout of a material can be defined as the tendency of freshly prepared cement paste to disintegrate upon early contact with the fluids such as blood or other liquids. The available study results on these characteristics of Biodentine does not reveal favourable results as it demonstrated a high washout with every sample used in the methodology [11].

The advantages of Biodentine include reduced setting time, better handling and ease of manipulation, improved mechanical properties, biocompatibility, preserves pulp vitality, which promotes pulp healing and helps in remineralisation of dentine [1,2]. However, this material possesses a few disadvantages, such as poor radio-opacity and lower washout resistance $[13,25]$.

\section{Clinical applications of Biodentine}

In restorative dentistry, Biodentine is used as a direct pulp capping material, which helps for reactionary dentine stimulation in indirect pulp capping. In endo- dontics, it is used for pulpotomy, endodontic repairs, and root-end filling material.

\subsection{Pulp capping agent}

Biodentine is used as a indirect pulp capping agent. Biodentine $^{\mathrm{TM}}$ can stimulate reactionary dentine, which is a natural barrier against bacterial invasions. The reactionary dentine formation stabilizes at three months, indicating that the stimulation process is stopped when a sufficient dentine barrier is formed [26]. It causes early mineralization by releasing TGF$\beta 1$ from pulpal cells to encourage pulp healing and by odontoblast stimulation for dentine bridge formation to protect the pulp. In contrast to Dycal, which is associated with tissue necrosis and inflammation during the initial time of installation, Biodentine has a welllocalized pattern (full dentinal bridge development) and no inflammatory reaction histologically. A clinical trial conducted by Septodont suggested that the Biodentine $^{\mathrm{TM}}$ could be used in direct pulp capping indications with a reasonable success rate. Perard et al. [27] assessed the biological effects of Biodentine for use in pulp-capping treatment on pseudo-odontoblastic and pulp cells. They found that MTA and Biodentine modify the proliferation of pulp cell lines. Nowicka et al. [28] concluded that Biodentine had similar efficacy to MTA in the clinical setting and can be considered an alternative to MTA in pulp capping treatment because it preserves pulp vitality and promotes its healing.

\subsection{Dentine substitute}

Due to its dentine like mechanical properties, Biodentine is used as a permanent dentine substitute under a composite, especially in deep carious teeth. The absence of aluminates results in less brittleness and is thus used as an ideal base under restorations. A study conducted by Septodont to compare the Biodentine with Filtek ${ }^{\mathrm{TM}} \mathrm{Z} 100$ as posterior restorative material showed that Biodentine ${ }^{\mathrm{TM}}$ has easy handling, excellent anatomic form, perfect marginal adaption, and establishes a very good interproximal contact [1].

\subsection{In vital pulpotomy}

Biodentine is also utilised in a pulpotomy, which is a vital pulp therapy. It is commonly employed in pediatric dentistry and involves amputation of the pulp chamber and material placement to preserve the radicular pulp tissue vitality. It is preferred when the coro- 
nal pulp tissue is inflamed, and direct pulp capping is not suitable. The success rate of vital pulpotomy with Biodentine is higher than that of MTA and Pulpotec [29 $-31]$.

\subsection{Endodontic repair material for perforations}

The endodontic indications of Biodentine ${ }^{\mathrm{TM}}$ are similar to the normal calcium silicate-based materials, like the Portland cements and MTA. Biodentine is recommended for perforation repair, the formation of apical plug and furcation repair.

\subsection{Root-end filling material}

To evaluate this application, Soundappan et al. [32] compared MTA, IRM and Biodentine as a retrograde filling material and found that at $1 \mathrm{~mm}$ level, there was no difference among tested materials. Still, at $2 \mathrm{~mm}$ level MTA was superior to both IRM and Biodentine. The results reveal that further research is required before Biodentine can be advocated as root-end filling material. Biodentine as root-end filling material has also been advised because of its better consistency, better handling, safety and faster setting time.

\section{Advantages of Biodentine Over M T A [5, 33 - 35 5]}

- BiodentineTM consistency is better suited to clinical use than MTA.

- BiodentineTM presentation ensures better handling and safety than MTA.

- BiodentineTM exhibits better mechanical properties than MTA.

- BiodentineTM does not require a two-step restoration procedure as in the case of MTA.

- As the setting is faster, there is a lower risk of bacterial contamination than with MTA.

Despite a few contradicting reports, numerous studies support this substance in terms of physical and therapeutic characteristics $[19,36,37]$.

\section{Conclusion}

Biodentine, a popular tricalcium silicate-based dentine replacement and repair material, has been evaluated in several aspects since its launching in 2009. Despite a few inconsistent results, various investigations have demonstrated that the Biodentine is superior in terms of physical and clinical features. Biodentine holds promise for clinical dental procedures as a biocompatible and easily handled product with a short setting time. As more research is performed regarding this exciting alternative to MTA, we will be provided with more reliable data and confidently implement Biodentine into routine clinical applications.

Conflicts of interest: Authors declared no conflicts of interest.

\section{Financial support: None}

\section{References}

1. Singh H, Kaur M, Markan S, Kapoor P, Biodentine: A promising dentine substitute. Interdiscipl Med Dent Sci. 2014; 2(5):1-5.

2. Septodont Biodentine ${ }^{\mathrm{TM}}$ Active Biosilicate Technology $^{\text {TM }}$. Scientific file 2010. Paris, France

3. Wilson AD, Kent BE. A new translucent cement for dentistry. The glass ionomer cement. See comment in PubMed Commons below Br Dent J. 1972;132:133135. https://doi.org/10.1038/sj.bdj.4802810

4. Torabinejad M, Watson TF, Pitt Ford TR. Sealing ability of a mineral trioxide aggregate when used as a root end filling material. J Endod. 1993;19: 591-595. https://doi.org/10.1016/S0099-2399(06)80271-2

5. Torabinejad M, Hong CU, McDonald F, Pitt Ford TR. Physical, and chemical properties of a new rootend filling material. J Endod. 1995; 21: 349-353. https://doi.org/10.1016/S0099-2399(06)80967-2

6. Torabinejad M, Rastegar AF, Kettering JD, Pitt Ford TR. Bacterial leakage of mineral trioxide aggregate as a root-end filling material. J Endod. 1995; 21: 109112. https://doi.org/10.1016/S0099-2399(06)80433-4

7. Ford TR, Torabinejad M, Abedi HR, Bakland LK, Kariyawasam SP. Using mineral trioxide aggregate as a pulp-capping material. J Am Dent Assoc. 1996;127:1491-1494. https://doi.org/10.14219/ jada.archive. 1996.0058

8. Torabinejad M, Hong CU, Pitt Ford TR, Kettering JD. Cytotoxicity of four root end filling materials. J Endod. 1995; 21: 489-492. https://doi.org/10.1016/ S0099-2399(06)80518-2

9. Torabinejad M, Pitt Ford TR, McKendry DJ, Abedi HR, Miller DA, et al. Histologic assessment of Mineral Trioxide aggregate as a root end filing in monkeys. J Endodon. 1997; 23: 225-228. https:// doi.org/10.1016/S0099-2399(97)80051-9

10. Kadali NS, Alla RK, Guduri V, Ramaraju AV, Sajjan S, Rudraraju VR. Mineral Trioxide Aggregate: An overview of composition, properties and clinical applications. Int J Dent Mater. 2020;2(1):11-8. https:// doi.org/10.37983/IJDM.2020.2103

11. Chessmann CR, Asavapisit S Effect of calcium chlo- 
ride on the hydratation and leaching of lead-retarded cement. Cem Concr Res. 1999;29: 885-892. https:// doi.org/10.1016/S0008-8846(99)00053-8

12. Caron G, Azérad J, Faure MO, Machtou P, Boucher $Y$. Use of a new retrograde filling material

(Biodentine) for endodontic surgery: two case reports. Int J Oral Sci. 2014; 6(4):250-3.

https://doi.org/10.1038/ijos.2014.25

13. Taylor HFW. Cement chemistry. $2^{\text {nd }}$ Edition, London, Thomas Telford Publishing, 1997.

14. Gandolfi, M.G.; Siboni, F., Prati, C. Chemicalphysical properties of TheraCal, a novel light-curable MTA-like material for pulp-capping. Int. Endod. J. 2012; 45, 571-579. https://doi.org/10.1111/j.13652591.2012.02013.x

15. Garrault S, Behr T, Nonat A. Formation of the C-S-H Layer during early hydration of tricalcium silicate grains with different sizes. J Phys Chem B. 2006; 110: 270-275. https://doi.org/10.1021/jp0547212

16. Cabeza M, Keddam M, Novoa XR, Sanchez I, Takenouti H. Impedance Spectroscopy to characterize the pore structure during the hardening process of Portland cement paste Electrochim Acta. 2006; 51: 1831-1841.

https://doi.org/10.1016/j.electacta.2005.02.125

17. Andrale C, Blanco V, Collazo A, Keddam M, Novoa $\mathrm{XR}$, et al. Cement paste hardening process studied by impedance spectroscopy. Electrochim Acta. 1999 44: 4314-4318. https://doi.org/10.1016/S0013-4686(99) 00147-4

18. M. B. Kayahan, M.H. Nekoofar, A. Mc Cann et al., Effect of acid etching procedures on the compressive strength of 4 calcium silicate-based endodontic cements. J Endodont. 2013;39(12)1646-1648. https:// doi.org/10.1016/j.joen.2013.09.008

19. G. Koubi, P. Colon, J.-C. Franquin et al., Clinical evaluation of the performance and safety of a new dentine substitute, Biodentine, in the restoration of posterior teeth - a prospective study, Clinic Oral Investig, 2013;17(1):243-249. https://doi.org/10.1007/ s00784-012-0701-9

20. Grech L, Mallia B, Camilleri J. Investigation of the physical properties of tricalcium silicate cementbased root-end filling materials. Dent Mater. 2013;29 (2):e20-8.

https://doi.org/10.1016/j.dental.2012.11.007

21. O'Brien WJ. Dental Materials and their Selection. 4th Edition, Canada, Quintessence Publishing Co., 2008.

22. Gandolfi MG, Siboni F, Polimeni A, Bossu M, Riceitiello F, Rengo S,Prati C.In vitro screening of the apatite forming ability, biointeractivity andphysical properties of a tricalcium silicate material for Endodontics and Restorative Dentistry. Dent J. 2013; 1: 41 -60. https://doi.org/10.3390/dj1040041

23. Vallés M, Mercadé M, Duran-Sindreu F, Bourdelande JL, Roig M. Influence of light and oxygen on the color stability of five calcium silicate-based materials. J
Endod. 2013;39: 525-528. https://doi.org/10.1016/ j.joen.2012.12.021

24. Laurent P, Camps J, About I. Biodentine ${ }^{\mathrm{TM}}$ induces TGF-I ${ }^{2} 1$ release from human pulp cells and early dental pulp mineralization. Int Endod J. 2012; 45: 439448.

https://doi.org/10.1111/j.1365-2591.2011.01995.x

25. Allen AJ, Thomas JJ, Jennings HM. Composition and density of nanoscale calcium-silicate-hydrate in cement. Nat Mater. 2007; 6: 311-316. https://doi.org/10.1038/nmat1871

26. Shayegan A, Jurysta C, Atash R, Petein M, Abbeele AV. Biodentineused as a pulp-capping agent in primary pig teeth. Pediatr Dent. 2012; 34: e202-208.

27. Pérard M, Le Clerc J, Watrin T, Meary F, Pérez F, et al. Spheroid modelstudy comparing the biocompatibility of Biodentine and MTA. J Mater Sci Mater Med. 2013; 24: 1527-1534. https://doi.org/10.1007/ s10856-013-4908-3

28. Nowicka A, Lipski M, Parafiniuk M, Sporniak-Tutak $\mathrm{K}$, Lichota D, et al. Response of human dental pulp capped with biodentine and mineral trioxide aggregate. See comment in PubMed Commons below J Endod. 2013; 39: 743-747. https://doi.org/10.1016/ j.joen.2013.01.005

29. Luo Z, Li D2, Kohli MR3, Yu Q1, Kim S3, et al. Effect of Biodentineâ, $\notin$ onthe proliferation, migration and adhesion of human dental pulp stem cells. Seecomment in PubMed Commons below J Dent. 2014; 42: 490-497. https://doi.org/10.1016/ j.jdent.2013.12.011

30. Tran XV, Gorin C, Willig C, Baroukh B, Pellat B, et al. Effect of a calciumsilicate-based restorative cement on pulp repair. See comment in PubMedCommons below J Dent Res. 2012 91: 1166-1171. https:// doi.org/10.1177/0022034512460833

31. Zanini M, Sautier JM, Berdal A, Simon S. Biodentine induces immortalized murine pulp cell differentiation into odontoblast-like cells and stimulates biomineralization. See comment in PubMed Commons below J Endod. 2012; 38: 1220-1226. https://doi.org/10.1016/ j.joen.2012.04.018

32. Soundappan S, Sundaramurthy JL, Raghu S, Natanasabapathy V. Biodentine versus Mineral Trioxide Aggregate versus Intermediate Restorative Material for Retrograde Root End Filling: An Invitro Study. J Dent (Tehran). 2014;11: 143-149.

33. Camilleri J, Sorrentino F, Damidot D. Investigation of the hydration and bioactivity of radiopacified tricalcium silicate cement, Biodentine and MTA Angelus. Dent Mater. 2013; 29(5):580-93. ․ https:// doi.org/10.1016/j.dental.2013.03.007

34. Sarkar NK, Caicedo R, Ritwik P, Moiseyeva R, Kawashima I. Physiochemical basis of the biologic properties of mineral trioxide aggregate. J Endod. 2005;31 (2):97-100. doi.org/10.1097/01.DON.0000133155.04468.41 
35. Mandeep Kaur et al., MTA Versus Biodentin: A Comparative Analysis. J Clinic Diagnostic Res. 2017;11(8): ZG01-ZG05.

36. Villat C, Grosgogeat B, Seux D, Farge P. Conservative approach of a symptomatic carious immature permanent tooth using a tricalcium silicate cement (Biodentine): a case report. Restor Dent Endod. 2013;38(4):258-262. $\quad$ https://doi.org/10.5395/ rde.2013.38.4.258

37. Pawar AM, Kokate SR, Shah RA. Management of a large periapical lesion using Biodentine as retrograde restoration with eighteen months evident follow-up. J Conserv Dent. 2013;16(6):573-575. https:// doi.org/10.4103/0972-0707.120934 